\title{
Hypersensitivity pneumonitis
}

\author{
H Khalfey, MB ChB, FCP SA, Cert Pulm SA \\ Pulmonologist, Life Vincent Pallotti Hospital, Pinelands, Cape Town
}

Corresponding author: H Khalfey (hkhalfey@telkomsa.net)

\begin{abstract}
Hypersensitivity pneumonitis (HP) refers to the inflammatory lung condition that arises from inhalational exposure to various (mostly organic) antigens with the development of lymphocytic alveolitis and granulomatous pneumonitis. A myriad of antigens have been implicated and the list continues to grow. The clinical features are varied, implicated antigens protean, and the investigations complementary in making a diagnosis, but the condition remains a difficult one to diagnose, mostly due to a lack of clinical suspicion. In this article we discuss HP, its aetiology, clinical features as well as diagnosis and management.
\end{abstract}

S Afr Resp J 2015;21(3):70-76. DOI:10.7196/10.2015.v21i3.70

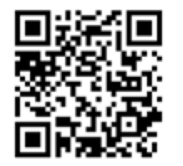

As early as 1713, an Italian medical professor by the name of Bernadino Ramazzini recorded the health hazards associated with 52 occupations. In this document he noted that: 'Almost all who make a living by sifting or measuring grain are short of breath and cachectic and rarely reach old age; in fact, they are very liable to lapse into orthopnoea and finally dropsy. ${ }^{[1]}$ With this description, Ramazzini essentially provided the first description of hypersensitivity pneumonitis (HP) with the development of chronic respiratory failure and cor pulmonale. Subsequently in 1932, the first detailed descriptions of HP were made following an outbreak in 10 employees at a company that manufactured railroad ties. ${ }^{[2]}$ These employees, who were required to strip bark from maple logs, developed symptoms of dyspnoea, cough, night sweats, weight loss and sputum production. It was subsequently discovered that beneath the bark of the maple logs a black sooty dust was present from which a fungus called Cryptostroma corticale was isolated. The chest X-ray and clinical features were compatible with what we now accept as HP.

HP has long been considered an orphan disease, and over the last 10 - 15 years there remains one intriguing question - why do only a small percentage of those who are exposed develop the disease? There is a lack of consensus as to the definition of HP and this is reflected in the different definitions suggested by two major groups of international experts. The National Heart, Lung, and Blood Institute and the Office of Rare Diseases (NHLBI/ORD) workshop report defines $\mathrm{HP}$ as 'a complex health syndrome of varying intensity, clinical presentation, and natural history. HP is the result of an immunologically induced inflammation of the lung parenchyma in response to inhalation exposure to a large variety of antigens. ${ }^{\left[{ }^{[3]}\right.}$ The HP Study group defined HP as 'a pulmonary disease with symptoms of dyspnoea and cough resulting from the inhalation of an antigen to which the patient has been previously sensitised. ${ }^{[4]}$ More recently, HP has been accepted as a pulmonary disease consisting of a spectrum of granulomatous, interstitial, bronchiolar and alveolarfilling lung diseases with or without systemic manifestations (fever and weight loss) caused by the inhalation of a wide variety of organic aerosols and low molecular weight (LMW) chemical antigens to which the subject is sensitised and hyper-responsive. Sensitisation and exposure alone in the absence of symptoms do not define the disease, which is characterised by a lymphocytic alveolitis and granulomatous pneumonitis, usually with improvement or complete recovery if exposure ceases, otherwise it leads to interstitial fibrosis if exposure continues. ${ }^{[5]}$

\section{Aetiology}

A wide group of causative antigens have been described for HP and new sources are continually being recognised (Table 1 ). The most commonly implicated antigens in the disease process are derived from thermophilic actinomycetes, such as Saccharopolyspora rectivirgula (which causes farmer's lung) following exposure to mouldy hay, and others that cause Bagassosis and cheese-washer's lung, as well as antigen derived from protein in the droppings, feathers or serum of birds (such as pigeons, budgerigars, ducks, parrots, etc.) which cause bird-fancier's lung. ${ }^{[6,7]}$ Increasingly duck and goose down used in duvets and feather pillows have been implicated as possible causes for chronic HP, often mistakenly labelled as idiopathic pulmonary fibrosis (IPF) ${ }^{[8]}$ Some LMW chemicals such as isocyanates (used in polyurethane foams, paints and plastics), zinc, inks and dyes can act as haptens to induce HP. It may be useful to consider the implicated antigens in three groups: microbial (fungal, bacterial, mycobacterial), animal proteins (bird feathers, droppings and serum) and LMW chemicals (isocyanates).

\section{Epidemiology}

The prevalence of HP varies considerably around the world and is dependent on a number of factors including disease definition, diagnostic methods, occupational exposures (type and intensity), geographic conditions, industrial and agricultural practices, as well as host risk factors. Bird-fancier's lung is usually the most common form of HP. HP is an uncommon condition that has been shown to make up $4-15 \%$ of all interstitial lung diseases ${ }^{[9]}$ and in Britain the incidence has been found to be 0.9 cases per 100000 person-years. ${ }^{[10]}$ What remains an enigma is the low proportion of patients who develop disease despite more widespread exposure, as was demonstrated in French dairy farmers, where only $0.5-3.0 \%$ developed disease. ${ }^{[11]}$ In South Africa, in a single-centre tertiary 
Table 1. Common antigens implicated in HP

\begin{tabular}{|c|c|c|}
\hline Disease & Antigen & Source of antigen \\
\hline \multicolumn{3}{|c|}{ Microbial - fungal and bacterial } \\
\hline Farmer's lung (FLD) & Saccharopolyspora rectivirgula & Mouldy hay, grain \\
\hline Bagassosis & Thermoactinomyces vulgaris & Mouldy sugarcane \\
\hline Maple bark stripper’s lung & Cryptostroma corticale & Mouldy maple bark \\
\hline Cheese-washer's lung & Penicillium casei, Aspergillus clavatus & Mouldy cheese \\
\hline Hot tub lung & Mycobacterium avium complex & Hot tub mists \\
\hline Summer-type pneumonitis & Trichosporon cutaneum & Contaminated old Japanese houses in summer months \\
\hline \multicolumn{3}{|l|}{ Animal proteins } \\
\hline Bird-fancier's lung (BFL) & Avian droppings, serum, feathers & Pigeons, budgerigars, parrots, ducks \\
\hline Animal-handler's lung & Rats, gerbils, hamsters & Urine, serum, fur \\
\hline \multicolumn{3}{|c|}{ Low molecular weight chemicals } \\
\hline Painter's lung & Isocyanates & Paint hardeners \\
\hline Plastic-worker’s lung & Anhydrides & Plastic components \\
\hline
\end{tabular}

referral hospital over a period of 30 years, 40 patients were diagnosed with HP due to bird exposure. ${ }^{[12]}$ In this group there was no gender difference, $30 / 40(75 \%)$ were of mixed race and 10/40 (25\%) were white subjects, with no black or Asian subjects. The age range at presentation was 13 - 75 years (mean 49.2 (standard deviation 15.4) years). Fifty-five per cent were non-smokers, $20 \%$ ex-smokers and $25 \%$ were current smokers.

\section{Pathogenesis}

While up to $50 \%$ of exposed subjects develop sensitisation with positive antibodies, only about $3-15 \%$ of bird fanciers develop HP. ${ }^{[13]}$ This suggests that the phenotypic expression of disease depends on host and environmental factors. The underlying immune mechanisms implicated in disease development have been demonstrated to be a combination of a Type III hypersensitivity (in acute HP) and Type IV delayed-type hypersensitivity (in chronic HP). A two-hit hypothesis has been postulated where genetic susceptibility or environmental factors serve as the first hit and increase the risk of development of disease after antigen exposure (second hit). ${ }^{[14]}$ There are few studies on the underlying genetic susceptibility in HP and available data increasingly point to abnormalities in the antigen processing and presentation pathways of the immune system. Polymorphisms associated with HLA-DR and DQ have been associated with increased risk for HP in populations with different genetic backgrounds. ${ }^{[15,16]}$ PSMB8 is an immunoproteasome catalytic subunit that is important in the generation of peptides presented by MHC class 1 molecules, and the PSMB8 KQ genotype has been found with increased frequency in subjects with HP. ${ }^{[17]}$ One study reported that Mexican patients with HP had increased expression of alleles Gly-637 and genotypes Asp637/Gly-637 and Pro661/Pro661 on the TAP1 (transporters associated with antigen processing 1) gene, which may lead to an exacerbated immune response and hence increased susceptibility to developing HP. ${ }^{[18]}$

There is ongoing research into the immunopathogenesis of HP and we are likely to learn more in the future about the immune tolerance occurring in most exposed individuals. Regulatory $\mathrm{T}$ cells $\left(\mathrm{T}_{\text {reg }}\right)$ may play an important role in this process, as has been shown in in vitro studies. ${ }^{[19,20]}$

In addition to underlying genetic susceptibility it has been shown that environmental factors such as exposure to parainfluenza viral infections in mice ${ }^{[21]}$ and pesticide exposure in farmers may increase susceptibility to development of clinical HP. ${ }^{[22]}$

The effects of smoking are interesting in that paradoxically smokers appear to have a reduced susceptibility to the development of HP and $95 \%$ of HP cases occur in non-smokers. ${ }^{[23]}$ This may be due to a decrease in the production of specific antibodies to inhaled organic antigens due to various immunosuppressive effects of tobacco smoke. Despite these relative protective effects of smoking, the smokers who do develop HP have lower vital capacities and a poorer 10-year survival in comparison with non-smokers. ${ }^{[24]}$

\section{Clinical features}

Three clinical forms of HP have been described: acute, subacute and chronic. However, it is often difficult to distinguish subacute HP from either acute or chronic as there is often overlap in clinical features, which blurs this distinction.

\section{Acute HP}

Patients typically give a history of flu-like symptoms occurring 4 - 8 hours following exposure to antigen and complain of dry cough, dyspnoea, fever, rigors, myalgia and malaise, which reach peak intensity at 12 - 24 hours and usually resolve completely within 48 hours if exposure ceases. These episodes will recur upon subsequent re-exposure to the antigen and are usually more intense. Clinical examination will reveal an acutely ill patient with tachypnoea, tachycardia, bibasal inspiratory crackles on auscultation of the chest and, in severe cases, acute respiratory failure evident on arterial blood gas analysis. Serum precipitating antibodies are usually positive in most cases and chest X-ray will reveal bilateral patchy or diffuse reticulonodular infiltrates mostly in the lower zones, with apical 
sparing. High-resolution computerised tomography scanning (HRCT) will typically show multiple small nodules with bilateral areas of ground-glass opacification, predominantly in the bases. Spirometry usually reveals a restrictive pattern with a reduced gas transfer. Both spirometry and radiology may often return to normal within 4 - 6 weeks if antigen exposure ceases.

\section{Subacute HP}

This is a difficult entity to distinguish from acute HP and usually occurs due to repeated low-grade exposure to antigens with the development of similar symptoms to acute HP that resolve within 24 hours of exposure, but due to ongoing exposure is associated with repeated bouts over a period of time. These tend to become more severe over time with longer recovery periods, but patients usually feel well inbetween attacks. The chest $\mathrm{X}$-ray may be completely normal in between attacks but usually demonstrates fine nodular infiltrates in the mid to upper zones. The HRCT may show areas of linear fibrosis due to repeated bouts of inflammation with areas of micronodules and mosaic attenuation in the mid to upper zones. Pulmonary function tests usually show mild restriction with or without a reduced gas transfer.

\section{Chronic HP}

Chronic HP is the form most commonly seen by pulmonologists, as patients most often present late or acute and subacute forms are not recognised as such. Chronic $\mathrm{HP}$ occurs in about $5 \%$ of patients with $\mathrm{HP}^{[25]}$ and develops insidiously over months to years in those with ongoing exposure and is usually irreversible. Patients usually present with chronic, progressive cough often with sputum production and progressive dyspnoea. Examination usually reveals tachypnoea with bibasal fine inspiratory crackles. Clubbing may be present and usually represents a poorer prognosis. ${ }^{[26]}$ Chronic respiratory failure occurs in severe cases leading to cor pulmonale. In chronic HP, precipitating antibodies or specific IgG may be negative if there is time latency between exposure and presentation. The chest X-ray typically shows features of volume loss with bilateral diffuse reticulonodular infiltrates with coarse linear opacities and reticulation in an upper and mid-zone distribution. Multiple areas of fibrosis with patchy ground-glass opacification and centrilobular nodularity with mosaic attenuation on expiratory views are usual. Honeycombing may also be present, which makes chronic HP difficult to distinguish from IPF. The lung function tests usually demonstrate restriction with reduced lung volumes and a reduced gas transfer. In up to $10 \%$, an obstructive defect may be evident. ${ }^{[27]}$

\section{Diagnosis}

No single diagnostic biomarker or procedure exists to confirm a diagnosis of HP and the clinician is thus faced with a diagnostic dilemma. HP lacks unique features that distinguish it from other interstitial lung diseases, and a diagnosis relies on a high index of suspicion when a history of antigen exposure is obtained, together with a constellation of clinical, radiological, laboratory and pathological findings.

\begin{tabular}{|c|c|c|c|}
\hline Stage of disease & References & Sample size & Findings $^{\dagger}$ \\
\hline \multirow[t]{6}{*}{ Acute } & \multirow[t]{6}{*}{ Cormier et al..$^{[30]}$} & \multirow[t]{6}{*}{$N=20$} & Ground-glass opacities \\
\hline & & & Micronodules \\
\hline & & & Mosaic perfusion \\
\hline & & & Emphysema \\
\hline & & & Honeycombing \\
\hline & & & $\begin{array}{l}\text { Mediastinal } \\
\text { lymphadenopathy }\end{array}$ \\
\hline \multirow[t]{8}{*}{ Subacute } & \multirow[t]{4}{*}{ Hansell et al. ${ }^{[31]}$} & \multirow{4}{*}{$\begin{array}{l}N=17 \text { (including } \\
9 \text { with pigeon } \\
\text { breeder's disease } \\
\text { and } 4 \text { with } \\
\text { Farmer's lung) }\end{array}$} & $\begin{array}{l}\text { Generalised increase in } \\
\text { attenuation of the lung }\end{array}$ \\
\hline & & & Nodular pattern \\
\hline & & & Reticular pattern \\
\hline & & & $\begin{array}{l}\text { Patchy air space } \\
\text { opacification }\end{array}$ \\
\hline & \multirow[t]{4}{*}{ Remy-Jardin et al. ${ }^{[32]}$} & \multirow[t]{4}{*}{$\begin{array}{l}N=21 \text { (pigeon } \\
\text { breeder's disease) }\end{array}$} & $\begin{array}{l}\text { Micronodular } \\
\text { pattern }(<5 \mathrm{~mm} \text { in } \\
\text { diameter })\end{array}$ \\
\hline & & & Ground-glass attenuation \\
\hline & & & Emphysematous change \\
\hline & & & Honeycombing \\
\hline \multirow[t]{7}{*}{ Chronic } & \multirow[t]{3}{*}{ Adler et al. ${ }^{[33]}$} & \multirow{3}{*}{$\begin{array}{l}N=16 \\
(\text { antigen = ?) }\end{array}$} & Fibrosis \\
\hline & & & Ground-glass attenuation \\
\hline & & & Nodules \\
\hline & \multirow[t]{4}{*}{ Remy-Jardin et al. ${ }^{[32]}$} & \multirow{4}{*}{$\begin{array}{l}N=24 \text { (pigeon } \\
\text { breeder's disease) }\end{array}$} & Honeycombing \\
\hline & & & Ground-glass attenuation \\
\hline & & & Micronodules \\
\hline & & & Emphysema \\
\hline \multicolumn{4}{|c|}{${ }^{*}$ Reproduced with permission from Lacasse. $\left.{ }^{[5]}\right]$} \\
\hline & & & \\
\hline
\end{tabular}

\section{Establish a history of exposure}

Careful history-taking is essential in order to elucidate a history of antigen exposure, which is the first critical prerequisite. This is especially difficult due to the fact that exposure may occur both directly and indirectly, such as may occur in bird-fancier's lung where exposures to birds may occur in parks, railway stations and neighbours' yards, as well as by birds in roofs of houses. Exposure to mouldy hay in barns is implicated in farmer's lung. To further add to the difficulties in history taking, avian antigen has been reported to persist in a house for 6 months after removal of the bird. ${ }^{[28]}$

\section{Imaging}

Imaging by chest X-ray and HRCT is not always diagnostic, but adds the most value in reaching a diagnosis. A confident 
radiological diagnosis has been shown to be accurate in up to $81 \%{ }^{\left[{ }^{[29]}\right.}$ Radiological features of each HP subtype have been addressed previously in this article. In acute HP, the following features have been described in descending order of frequency: groundglass opacities, micronodules, mosaic perfusion, emphysema, honeycombing and mediastinal lymphadenopathy. ${ }^{[30]}$ These usually have a lower and mid-zone predominance. In subacute HP, the most common features are a micronodular pattern followed by reticulation, patchy airspace opacification and in some cases honeycombing, emphysematous change and fibrosis which tend to have a mid-zone predominance as well. ${ }^{[31,32]}$ In chronic HP, the predominant HRCT finding is that of fibrosis with ground-glass attenuation, honeycombing and micronodules as well as

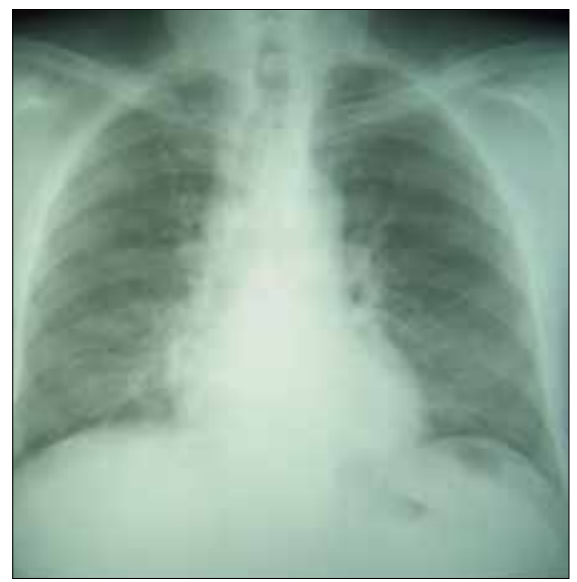

Fig. 1a. Postero-anterior (PA) chest radiograph of acute HP due to pigeons showing diffuse ground-glass opacification. Reproduced with permission from Professor Ainslie..$^{[12]}$

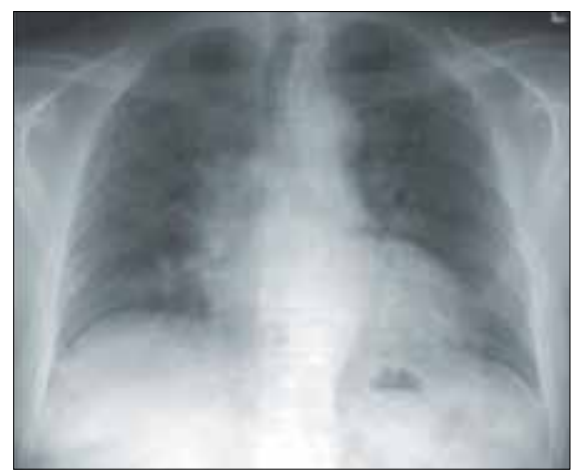

Fig. 1b. PA chest radiograph of patient with chronic HP due to pigeons showing small lungs with diffuse reticulonodular infiltration. Reproduced with permission from Professor Ainslie. ${ }^{[12]}$ emphysema. ${ }^{[32,33]}$ This often spares the bases but may be predominantly sub-pleural or peribronchovascular.

See Table 2, and Figures 1a and b and Figures $2 \mathrm{a}$ and $\mathrm{b}$.

\section{Specific circulating antibodies}

These techniques detect IgG to specific antigens and a positive result merely reflects sensitisation and not necessarily disease. A positive result can be obtained in up to $10 \%$ of farmers and $40 \%$ of pigeon breeders without any evidence of clinical disease. However, a positive test in the correct clinical scenario strongly supports the diagnosis of HP. ${ }^{[34,35]}$ A negative test, however, does not exclude disease. Positive specific antibodies were shown to be a significant predictor of disease in the HP study. ${ }^{[4]}$ Enzyme immunoassays have now largely replaced the precipitation techniques and have been shown to be a more reliable technique. The test has demonstrated varying sensitivity and specificity. In acute HP in bird-fancier's lung disease, antibody titres were markedly increased and showed

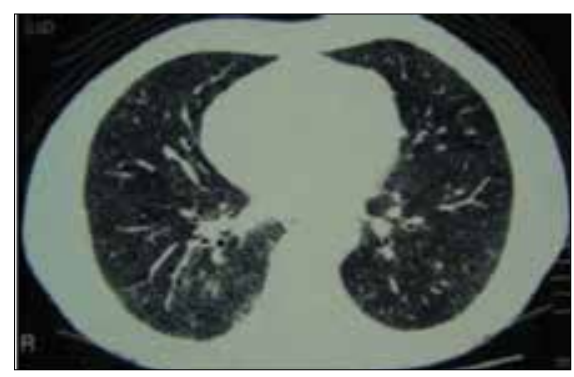

Fig. 2a. Inspiratory HRCT film in patient with acute HP due to pigeons showing patchy ground-glass opacification and multiple small centrilobular nodules. Reproduced with permission from Professor Ainslie. ${ }^{[12]}$

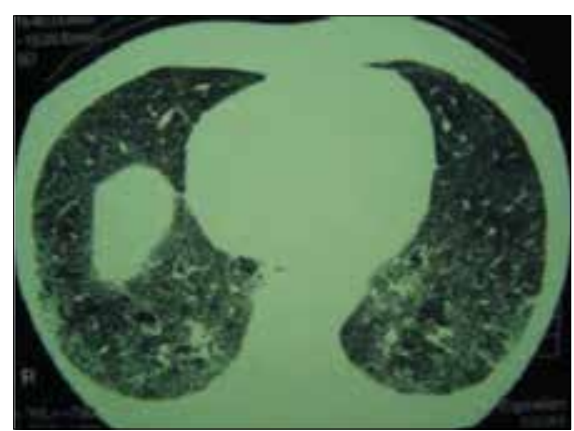

Fig. 2b. Expiratory HRCT film in patient with acute HP due to pigeons showing patchy gas trapping (mosaic attenuation pattern). Reproduced with permission from Professor Ainslie. ${ }^{[12]}$ high sensitivity and specificity ranging from 75 to $100 \%$, while in chronic HP, titres were only slightly increased with a sensitivity between 27 and $73 \%$ and specificity of 45 $100 \% \cdot{ }^{[36]}$ False negatives may also be seen across the disease spectrum and this depends on the latency period between symptoms and testing, laboratory techniques and panels of antigens tested, etc.

\section{Inhalational provocation test}

This involves the inhalation of $2 \mathrm{~mL}$ of pigeon dropping extract (PDE $340 \mu \mathrm{g} / \mathrm{mL}$ ) through a handheld nebuliser for a maximum period of 10 minutes. A number of parameters are recorded for 24 hours thereafter and a test is regarded as positive if three or more of the following are demonstrated: increased radiological abnormalities, increased $\mathrm{A}$-a gradient $>10 \mathrm{mmHg}$ or decrease in transfer factor (TLCO) of $>20 \%$, decrease in forced vital capacity $(\mathrm{FVC})>15 \%$, increase in peripheral white blood cell count (WCC) of $>30 \%$, increase in C-reactive protein (CRP) $>1.0 \mathrm{mg} / \mathrm{dl}$, increase in body temperature $>1{ }^{\circ} \mathrm{C}$ and/or development of systemic manifestations including chills and fatigue, development of respiratory symptoms such as cough and dyspnoea (Table 3 )..$^{[37,38]}$ Inhalational provocation testing has been considered to be the 'gold standard' by Morell, in whose series the test performed with a sensitivity of $92 \%$ and specificity of $100 \%$ in patients with bird-fancier's lung disease. ${ }^{[39]}$ Although it appears to be a useful test, it lacks standardisation with regards to antigen preparation, administration and monitoring and is not without risk to the patient. It is best conducted in research centres with expertise in the procedure.

\section{Table 3. Inhalation challenge testing}

Positive if 3 or more of the following:

Increased radiological abnormalities

Increased A-a gradient $>10 \mathrm{mmHg}$ or decrease in TLCO of $>20 \%$

Decrease in VC of $>15 \%$

Increase in peripheral WCC of $>30 \%$ Increase in CRP $>1.0 \mathrm{mg} / \mathrm{dL}$

Increase in body temperature $>1{ }^{\circ} \mathrm{C}$ and/or development of systemic manifestations including chills and fatigue

Development of respiratory symptoms - cough and dyspnoea 
Bronchoalveolar lavage (BAL)

Demonstrating BAL lymphocytosis is a highly sensitive method of determining lung inflammation in patients with suspected HP but the test lacks standardisation. BAL lymphocytosis $>50 \%$ characterises HP and distinguishes it from other conditions, but it may be lower in smokers and those with predominantly fibrotic disease. ${ }^{[5]}$ Asymptomatic exposed individuals may also have a lymphocytosis that represents a lowgrade alveolitis, while other conditions (such as sarcoidosis and organising pneumonia) may also have elevated BAL lymphocytes. Demonstrating a CD4/CD8 ratio $<1$ is suggestive of HP in up to $34 \%{ }^{[40]}$ but the ratio may be as high as that seen in sarcoidosis and is thus not recommended routinely anymore. ${ }^{[41,42]}$

\section{Biopsy}

Biopsy in the form of transbronchial biopsy or surgical lung biopsy is rarely needed for a diagnosis of acute HP. In chronic HP it is usually characterised by a triad of chronic

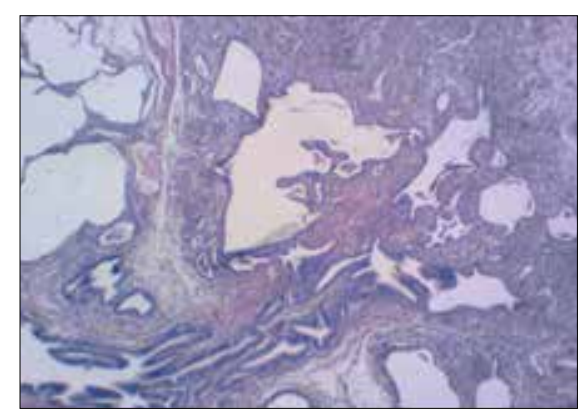

Fig. 3a. Low-power image of a surgical lung biopsy in a patient with chronic HP showing patchy peribronchiolar inflammatory process. inflammatory infiltrates along small airways (cellular bronchiolitis), diffuse interstitial infiltrates of inflammatory cells (lymphocytes and plasma cells) and scattered non-necrotising granulomas (Figs. 3a and 3b). ${ }^{[43]}$ Granulomas

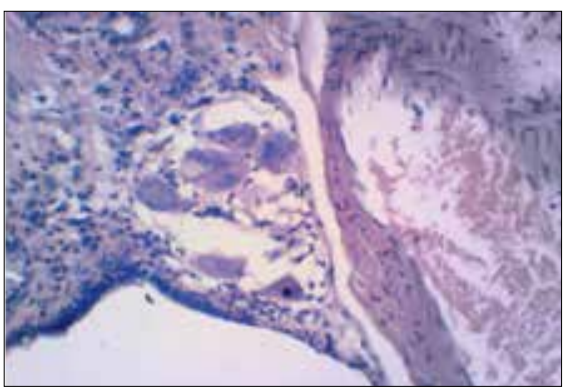

Fig. 3b. High-power image of a surgical lung biopsy in a patient with chronic HP showing a peribronchiolar granuloma with multinucleated giant cells.

Table 4. Proposed diagnostic criteria for HP for clinical purposes. ${ }^{*}$

\begin{tabular}{|c|c|c|}
\hline Author & Major criteria & Minor criteria \\
\hline \multirow[t]{7}{*}{ Terho $^{[45]}$} & \multirow{3}{*}{$\begin{array}{l}\text { 1. Exposure to offending antigens (revealed by history } \\
\text { aerobiological or microbiological investigations of the } \\
\text { environment, or measurements of antigen-specific IgG } \\
\text { antibodies) }\end{array}$} & 1. Basal crepitant rales \\
\hline & & 2. Impairment of the diffusing capacity (TLCO) \\
\hline & & \multirow{2}{*}{$\begin{array}{l}\text { 3. Oxygen tension (or saturation) of the arterial } \\
\text { blood either decreased at rest, or normal at } \\
\text { rest but decreased during exercise }\end{array}$} \\
\hline & $\begin{array}{l}\text { 2. Symptoms compatible with HP present and appearing or } \\
\text { worsening some hours after antigen exposure }\end{array}$ & \\
\hline & \multirow[t]{3}{*}{ 3. Lung infiltrations compatible with HP visible on chest X-ray } & $\begin{array}{l}\text { 4. Restrictive ventilation defect in the } \\
\text { spirometry }\end{array}$ \\
\hline & & 5. Histological changes compatible with HP \\
\hline & & $\begin{array}{l}\text { 6. Positive provocation test whether by work } \\
\text { exposure or by controlled inhalation } \\
\text { challenge }\end{array}$ \\
\hline \multirow[t]{4}{*}{ Richerson et al. ${ }^{[46]}$} & \multicolumn{2}{|l|}{$\begin{array}{l}\text { 1. The history and physical findings and pulmonary function tests } \\
\text { indicate an interstitial lung disease }\end{array}$} \\
\hline & \multicolumn{2}{|l|}{ 2. The $\mathrm{X}$-ray film is consistent } \\
\hline & \multicolumn{2}{|l|}{ 3. There is exposure to a recognised cause } \\
\hline & \multicolumn{2}{|l|}{ 4. There is antibody to that antigen } \\
\hline \multirow[t]{5}{*}{ Cormier et al. ${ }^{[47]}$} & 1. Appropriate exposure & 1. Recurrent febrile episodes \\
\hline & 2. Inspiratory crackles & 2. Decreased transfer factor (TLCO) \\
\hline & 3. Lymphocytic alveolitis (if BAL is done) & 3. Precipitating antibodies to HP antigens \\
\hline & 4. Dyspnoea & 4. Granulomas on lung biopsy (usually not required) \\
\hline & 5. Infiltrates on chest radiographs or HRCT & $\begin{array}{l}\text { 5. Improvement with contact avoidance or } \\
\text { appropriate treatment }\end{array}$ \\
\hline \multirow[t]{7}{*}{ Schuyler et al..$^{[48]}$} & 1. Symptoms compatible with HP & 1. Bibasilar rales \\
\hline & \multirow{2}{*}{$\begin{array}{l}\text { 2. Evidence of exposure to appropriate antigen by history or } \\
\text { detection in serum and/or BAL fluid antibody }\end{array}$} & 2. Decreased TLCO \\
\hline & & \multirow{5}{*}{$\begin{array}{l}\text { 3. Arterial hypoxaemia, either at rest or during } \\
\text { exercise }\end{array}$} \\
\hline & 3. Findings compatible with HP on chest radiograph or HRCT & \\
\hline & 4. BAL fluid lymphocytosis & \\
\hline & 5. Pulmonary histological changes compatible with HP & \\
\hline & 6. Positive natural challenge & \\
\hline
\end{tabular}


occur in varying degrees across studies, and in an epidemiologic survey in Japan, it was demonstrated in $16.7 \%$ with BFL, $44.4 \%$ with summer-type HP and $60 \%$ with isocyanate HP. ${ }^{[44]}$ Surgical lung biopsy was only helpful in $37 \%$ in the HP study. ${ }^{[4]}$

\section{Diagnostic criteria}

The diagnosis of HP remains a difficult one and, as mentioned before, rests on a high index of suspicion in a patient with a history of exposure, with compatible clinical and radiological features complemented by further investigations. A number of diagnostic criteria have been studied and recommended but none have been effectively validated. Most diagnostic criteria essentially correspond with definitions of the disease (Table 4). ${ }^{[45-48]}$ The HP study was a multi-centred, multinational study that recruited patients with suspected HP with the aim of developing a predictive tool for the diagnosis of HP. ${ }^{[4]} \mathrm{HP}$ was diagnosed in 199 out of 661 subjects in the study and they identified six significant predictors useful in assisting clinicians to arrive at a more accurate estimate of probability of HP. The following were identified as significant predictors:

The probability of HP in the HP study ranged from $98 \%$, when all 6 predictors were present, to $0 \%$ when there were none. The authors

Table 5. Significant predictors of NSCLC

\begin{tabular}{lll}
\hline Predictor & $\begin{array}{l}\text { Odds ratio } \\
\text { (OR) }\end{array}$ & $\begin{array}{l}\text { 95\% confidence } \\
\text { interval (CI) }\end{array}$ \\
\hline $\begin{array}{l}\text { Exposure to a known offending } \\
\text { antigen }\end{array}$ & 38.8 & $(11.6-129.6)$ \\
$\begin{array}{l}\text { Symptoms 4 - 8 hours after } \\
\text { exposure }\end{array}$ & 7.2 & $(1.8-28.6)$ \\
$\begin{array}{l}\text { Positive precipitating } \\
\text { antibodies }\end{array}$ & 5.3 & $(2.7-10.4)$ \\
$\begin{array}{l}\text { Inspiratory crackles } \\
\text { Recurrent episodes of } \\
\text { symptoms }\end{array}$ & 4.5 & $(1.8-11.7)$ \\
Weight loss & 3.3 & $(1.5-7.5)$ \\
& 2.0 & $(1.0-3.9)$
\end{tabular}

suggested that a probability of $>90 \%$ is sufficient to rule in and a probability $<10 \%$ to rule out HP, especially in areas of high and low prevalence respectively. The results of this study are thus useful to assess probability of HP but are not by definition diagnostic criteria. They may be useful in reducing the number of unnecessary invasive procedures such as BAL and biopsy.

\section{Treatment}

Complete antigen avoidance is the first and most important step in managing HP. In acute HP, this is usually sufficient to prevent disease progression. The treatment of subacute and chronic HP is usually the same. Evidence-based guidelines are lacking, and the strongest available evidence comes from a randomised, placebo-controlled trial of 36 patients with farmer's lung disease who were randomised to receive either $40 \mathrm{mg}$ prednisolone daily, tapering over 8 weeks, or a placebo. ${ }^{[49]}$ This study showed no significant improvement in pulmonary function after 1 month of treatment apart from a small increase in the TLCO and there was no difference in the 5-year outcome. A reasonable recommendation by Selman ${ }^{[50]}$ is to start with
$0.5 \mathrm{mg} / \mathrm{kg}$ of prednisone for $4-6$ weeks in patients with chronic HP, followed by a slow wean to a maintenance dose of $10 \mathrm{mg} /$ day, which should eventually be weaned and discontinued in a manner similar to the treatment of sarcoidosis. Given the risks of systemic steroid therapy, it would be appropriate to wean as soon as possible in the event of a lack of response.

\section{Prognosis}

The long-term outcome in HP is highly variable and is related to the duration, type and intensity of antigen exposure. In a populationbased cohort study, patients with HP had a markedly increased risk of death (hazard ratio $2.98,95 \%$ CI 2.05 - 4.33). ${ }^{[2]}$ The 5 -year mortality has been noted to be $29 \%$ and strongly related to the presence of fibrosis and honeycombing on HRCT scan. ${ }^{[51]}$ In Ainslie's South African series in bird-fanciers' lung ${ }^{[12]}$ with a mean follow-up period of 45.6 months, $18 \%$ died, with a suggestion that severe restriction on spirometry and a poorer response to steroids may be associated with poor outcome. Traction bronchiectasis and extent of honeycombing have shown to be superior to forced expiratory volume in 1 second $\left(\mathrm{FEV}_{1}\right), \mathrm{FVC}$ and gas transfer for predicting mortality ${ }^{[52]}$ Pulmonary hypertension holds a poorer prognosis and death may occur in up to $20 \% \cdot{ }^{[53]}$ As in IPF, there is an increased prevalence of lung cancer, with a reported prevalence of $10.6 \%{ }^{[54]}$

\section{Conclusion}

HP remains a complex condition that is difficult to diagnose. Probability tools exist which are useful in reaching a diagnosis and may reduce the need for BAL and lung biopsy. The disease is completely reversible if detected early, and a high index of suspicion is required in order to detect and eliminate antigen exposure. Systemic steroids remain the mainstay of treatment but robust studies are lacking. The mechanisms of immune tolerance remain a point of interest and ongoing research.

\section{Acknowledgements}

Professor Gillian Ainslie - Pulmonologist, University of Cape Town - for the use of her chest X-ray and HRCT images.

Dr Fabio Crabbia and Dr Ellen Bolding - Histopathologists, Pathcare Cape Town - for the pathology slides.

Professor Yves Lacasse - Centre de Pneumologie, Université Laval, Hôpital Laval, 2725 Chemin Ste-Foy, Ste-Foy, Quebec, G1V 4G5, Canada - for Tables 2 and 4.

\section{References}

1. Ramazzini B. Diseases of Workers (Wright WC, trans). New York, NY: Hafner, 1964:243.

2. Towey JW, Sweany HC, Huron WH. Severe bronchial asthma apparently due to fungus spores found in maple bark. JAMA 1932;99(6):453-459. [http://dx.doi.org/10.1001/ jama.1932.02740580021005]

3. Fink JN, Ortega HG, Reynolds HY, et al. Needs and opportunities for research in hypersensitivity pneumonitis. Am J Respir Crit Care Med 2005;171: 792-798. [http:// dx.doi.org/10.1164/rccm.200409-1205WS]

4. Lacasse Y, Selman M, Costabel U, et al. Clinical diagnosis of hypersensitivity pneumonitis. Am J Respir Crit Care Med 2003;168:952-958. [http://dx.doi. org/10.1164/rccm.200301-137OC]

5. Lacasse Y, Girard M, Cormier Y. Recent advances in hypersensitivity pneumonitis. Chest 2012;142:208-217. [http://dx.doi.org/10.1378/chest.11-2479]

6. Bice DE, Salvaggio LE, Hoffman EO, Salvaggio J. Adjuvant properties of Microspolyspora faeni. J Allergy Clin Immunol 1976;55:267-274. 
7. Riley DJ, Saldana M. Pigeon breeder's lung: Subacute course and the importance of indirect exposure. Am Rev Respir Dis 1973;107:456-460.

8. Morell F, Villar A, Montero MA. Chronic hypersensitivity pneumonitis in patients diagnosed with idiopathic pulmonary fibrosis: A prospective case-cohort study. Lancet Respir Med 2013;1:685-694. [http://dx.doi.org/10.1016/S2213-2600(13)70191-7]

9. Thomeer MJ, Costabe U, Rizzato G, Poletti V, Demedts M. Comparison of registries of interstitial lung diseases in three European countries. Eur Respir J Suppl 2001;32:114s-118s

10. Solaymani-Dodaran M, West J, Smith C, Hubbard R. Extrinsic allergic alveolitis: Incidence and mortality in the general population. QJM 2007;100(4):233-237. [http:// dx.doi.org/10.1093/qjmed/hcm008]

11. Dalphin JC, Debieuvre D, Pernet D, et al. Prevalence and risk factors for chronic bronchitis and farmer's lung in French dairy farmers. Br J Ind Med 1993;50(10):941944. [http://dx.doi.org/10.1136/oem.50.10.941]

12. Ainslie GM. Birdfancier's hypersensitivity pneumonitis in South Africa: Clinical features and outcomes. South African Respiratory Journal 2013;19(2):48-53.

13. Patel AM. Hypersensitvity pneumonitis: Current concepts and future questions. J Allergy Clin Immunol 2001;108:661-670. [http://dx.doi.org/10.1067/ mai.2001.119570]

14. Selman M, Pardo A, King TE Jr. Hypersensitivity pneumonitis: Insights in diagnosis and pathobiology. Am J Respir Crit Care Med 2012;186(4):314-324. [http://dx.doi. org/10.1164/rccm.201203-0513CI]

15. Ando M, Hirayama K, Soda K, Okubo R, Araki S, Sasazuki T. HLA-DQw3 in Japanese summer-type hypersensitivity pneumonitis induced by Trichosporon cutaneum. Am Rev Respir Dis 1989;140:948-950. [http://dx.doi.org/10.1164/ajrccm/140.4.948]

16. Camarena A, Juarez A, Mejia M, et al. Major histocompatibility complex and tumor necrosis factor-alpha polymorphisms in pigeon breeder's disease. Am J Respir Crit Care Med 2001;163:1528-1533. [http://dx.doi.org/10.1164/ajrccm.163.7.2004023]

17. Camarena A, Aquino-Galvez A, Falfan-Valencia R, et al. PSMB8 (LMP7) but not PSMB9 (LMP2) gene polymorphisms are associated to pigeon breeder's hypersensitivity pneumonitis. Respir Med 2010;104:889-894. [http://dx.doi. org/10.1016/j.rmed.2010.01.014]

18. Aquino-Galvez A, Camarena A, Monta-o M, et al. Transporter associated with antigen processing (TAP) 1 gene polymorphisms in patients with hypersensitivity pneumonitis. Exp Mol Pathol 2008;84(2):173-177. [http://dx.doi.org/10.1016/j. yexmp.2008.01.002]

19. Kim JM, Rasmussen JP, Rudensky AY. Regulatory T cells prevent catastrophic autoimmunity throughout the lifespan of mice. Nat Immunol 2007;8:191-197. [http:// dx.doi.org/10.1038/ni1428]

20. Girard M, Israel-Assayag E, Cormier Y. Impaired function of regulatory T-cells in hypersensitivity pneumonitis. Eur Respir J 2011;37:632-639. [http://dx.doi. org/10.1183/09031936.00055210]

21. Cormier Y, Tremblay GM, Fournier M, Israel-Assayag E. Long-term viral enhancement of lung response to Saccharopolyspora rectivirgula. Am J Respir Crit Care Med 1994;149:490-494. [http://dx.doi.org/10.1164/ajrccm.149.2.8306051]

22. Hoppin JA, Umbach DM, Kullman GJ, et al. Pesticides and other agricultural factors associated with self-reported farmer's lung among farm residents in the Agricultural Health Study. Occup Environ Med 2007;64:334-341. [http://dx.doi.org/10.1136/ oem.2006.028480]

23. Cormier Y, Gagnon L, Berube-Genest F, Fournier M. Extrinsic allergic alveolitis: The influence of cigarette smoking. Am Rev Respir Dis 1988;137:1104-1109. [http:// dx.doi.org/10.1164/ajrccm/137.5.1104]

24. Munakata M, Tanimura K, Ukita H, et al. Smoking promotes insidious and chronic farmer's lung disease, and deteriorates clinical outcome. Intern Med 1995; 34:966-971. [http://dx.doi.org/10.2169/internalmedicine.34.966]

25. Pozzi E. Extrinsic allergic alveolitis (hypersensitivity pneumonitis). In: Grassi C, Brambella C, Costabel U, et al., eds. Pulmonary Diseases. London: McGraw-Hil International, 1999:289-294

26. Sansores R, Salas J, Chapela R, Barquin N, Selman M. Clubbing in hypersensitivity pneumonitis: Its prevalence and possible prognostic role. Arch Intern Med 1990;150:1849-1851. [http://dx.doi.org/10.1001/archinte.1990.00390200053010]

27. Selman M, Vargas MH. Airway involvement in hypersensitivity pneumonitis. Curr Opin Pulm Med 1998;4:9-15. [http://dx.doi.org/10.1097/00063198-199801000-00003]

28. Craig TJ, Hershey J, Engler RJ, Davis W, Carpenter GB, Salata K. Bird antigen persistence in the home environment after removal of the bird. Ann Allergy 1992;69(6):510-512.

29. Tomiyama N, Müller NL, Johkoh T, et al. Acute parenchymal lung disease in immunocompetent patients: Diagnostic accuracy of high-resolution CT. Am J Roentgenol 2000;174(6):1745-1750. [http://dx.doi.org/10.2214/ajr.174.6.1741745]

30. Cormier Y, Brown M, Worthy S, Racine G, Muller NL. High-resolution computed tomographic characteristics in acute farmer's lung and in its follow-up. Eur Respir J 2000;16:56-60. [http://dx.doi.org/10.1034/j.1399-3003.2000.16a10.x]
31. Hansell DM, Moskovic E. High-resolution computed tomography in extrinsic allergic alveolitis. Clin Radiol 1991;43:8-12. [http://dx.doi.org/10.1016/S00099260(05)80345-9]

32. Remy-Jardin M, Remy J, Wallaert B, Muller NL. Subacute and chronic bird breede hypersensitivity pneumonitis: Sequential evaluation with CT and correlation with lung function tests and bronchoalveolar lavage. Radiology 1993;189:111-118. [http:// dx.doi.org/10.1148/radiology.189.1.8372179]

33. Adler BD, Padley SP, Muller NL, Remy-Jardin M, Remy J. Chronic hypersensitivity pneumonitis: High-resolution CT and radiographic features in 16 patients. Radiology 1992;185:91-95. [http://dx.doi.org/10.1148/radiology.185.1.1523340]

34. Cormier Y, Bélanger J , Durand P. Factors influencing the development of serum precipitins to farmer's lung antigen in Quebec dairy farmers. Thorax 1985;40(2):138142. [http://dx.doi.org/10.1136/thx.40.2.138]

35. Dalphin JC, Toson B, Monnet E, et al. Farmer's lung precipitins in Doubs (a department of France): Prevalence and diagnostic value. Allergy 1994;49(9):744-750. [http://dx.doi.org/10.1111/j.1398-9995.1994.tb02097.x]

36. Inase N, Unoura K, Miyazaki Y, Yasui M, Yoshizawa Y. Measurement of bird specific antibody in bird-related hypersensitivity pneumonitis. Nihon Kokyuki Gakkai Zasshi 2011;49(10):717-722.

37. Ramırez-Venegas A, Sansores RH, Perez-Padilla R, Carrillo G, Selman M. Utility of a provocation test for diagnosis of chronic pigeon breeder's disease. Am J Respir Crit Care Med 1998;158:862-869. [http://dx.doi.org/10.1164/ajrccm.158.3.9710036]

38. Ohtani Y. Inhalation provocation tests in chronic bird fancier's lung. Chest 2000;118(5):1382-1389. [http://dx.doi.org/10.1378/chest.118.5.1382]

39. Morell F, Roger A, Reyes L, Cruz MJ, Murio C, Mu-oz X. Bird fancier's lung: A series of 86 patients. Medicine (Baltimore) 2008;87:110-130. [http://dx.doi.org/10.1097/ MD.0b013e31816d1dda]

40. Caillaud DM. Bronchoalveolar lavage in hypersensitivity pneumonitis: A series of 139 patients. Inflamm Allergy Drug Targets 2012;11(1):15-19. [http://dx.doi. org/10.2174/187152812798889330]

41. Ando M, Konishi K, Yoneda R, Tamura M . Difference in the phenotypes of bronchoalveolar lavage lymphocytes in patients with summer-type hypersensitivity pneumonitis, farmer's lung, ventilation pneumonitis, and bird fancier's lung: Report of a nationwide epidemiologic study in Japan. J Allergy Clin Immunol 1991; 87(5):10021009. [http://dx.doi.org/10.1016/0091-6749(91)90423-l]

42. Wahlström J, Berlin M, Lundgren R, et al . Lung and blood T-cell receptor repertoire in extrinsic allergic alveolitis. Eur Respir J 1997;10(4):772-779.

43. Coleman A. Histologic diagnosis of extrinsic allergic alveolitis. Am J Surg Pathol 1988;12(7):514-518.

44. Yoshizawa Y. Chronic hypersensitivity pneumonitis in Japan: A nationwide epidemiologic survey. J Allergy Clin Immunol 1999;103(2 Pt 1):315-320. [http:// dx.doi.org/10.1016/s0091-6749(99)70507-5]

45. Terho EO. Diagnostic criteria for farmer's lung disease. Am J Ind Med 1986;10:329. [http://dx.doi.org/10.1002/ajim.4700100333]

46. Richerson HB, Bernstein IL, Fink JN, et al. Guidelines for the clinical evaluation of hypersensitivity pneumonitis. Report of the Subcommittee on Hypersensitivity Pneumonitis. J Allergy Clin Immunol 1989;84(5):839-844. [http://dx.doi. org/10.1016/0091-6749(89)90349-7]

47. Cormier Y, Lacasse Y. Keys to the diagnosis of hypersensitivity pneumonitis: The role of serum precipitins, lung biopsy, and high-resolution computed tomography. Clin Pulm Med 1996,3(2):72-77. [http://dx.doi.org/10.1097/00045413-199603000-00004]

48. Schuyler M, Cormier Y. The diagnosis of hypersensitivity pneumonitis. Chest 1997;111(3):534-536. [http://dx.doi.org/10.1378/chest.111.3.534]

49. Kokkarinen JI, Tukiainen HO, Terho EO. Effect of corticosteroid treatment on the recovery of pulmonary function in farmer's lung. Am Rev Respir Dis 1992;145(1):3-5. [http://dx.doi.org/10.1164/ajrccm/145.1.3]

50. Selman M. Hypersensitivity pneumonitis. In: Schwarz M, King TE Jr, eds. Interstitial lung disease, 5th ed. Shelton, CT: People’s Medical Publishing House-USA, 2011:597-625.

51. Pérez-Padilla R. Mortality in Mexican patients with chronic pigeon breeder's lung compared with those with usual interstitial pneumonia. Am Rev Respir Dis 1993;148(1):49-53. [http://dx.doi.org/10.1164/ajrccm/148.1.49]

52. Walsh SL, Sverzellati N, Devaraj A, Wells AU, Hansell DM. Chronic hypersensitivity pneumonitis: High resolution computed tomography patterns and pulmonary function indices as prognostic determinants. Eur Radiol 2012;22(8):1672-1679. [http://dx.doi.org/10.1007/s00330-012-2427-0]

53. Koschel DS, Cardoso C, Wiedemann B, Hoffken G, Halank M. Pulmonary hypertension in chronic hypersensitivity pneumonitis. Lung 2012;190:295-302. [http://dx.doi.org/10.1007/s00408-011-9361-9]

54. Kuramochi J. Lung cancer in chronic hypersensitivity pneumonitis. Respiration 2011;82(3):263-267. [http://dx.doi.org/10.1159/000327738]

55. Lacasse Y, Cormier Y. Review: Hypersensitivity pneumonitis. Orphanet Journal of Rare Diseases 2006;1:25. [http//:dx.doi.org/10.1186/1750-1172-1-25] 